\title{
Geographic distribution and description of four pelagic barnacles along the south east Pacific coast of Chile - a zoogeographical approximation
}

\author{
Distribución geográfica y descripción de cuatro especies de cirripedios pelágicos a lo largo \\ de la costa chilena del Pacífico sur este - una aproximación zoogeográfica
}

\author{
IVÁN HINOJOSA ${ }^{1}$, SEBASTIÁN BOLTAÑA ${ }^{1}$, DOMINGO LANCELLOTTI ${ }^{1}$, ERASMO MACAYA ${ }^{1}$, \\ PABLA UGALDE ${ }^{1}$, NELSON VALDIVIA ${ }^{1}$, NELSON VÁSQUEZ ${ }^{1}$, WILLIAM A. NEWMAN ${ }^{2}$ \& MARTIN THIEL ${ }^{1,3 *}$
}

\footnotetext{
${ }^{1}$ Facultad Ciencias del Mar, Universidad Católica del Norte, Larrondo 1281, Coquimbo, Chile

${ }^{2}$ Scripps Institution of Oceanography, La Jolla, CA 92093-0202, USA

${ }^{3}$ Centro de Estudios Avanzados en Zonas Áridas CEAZA, Coquimbo, Chile;

*e-mail for correspondence: thiel@ucn.cl
}

\begin{abstract}
The majority of zoogeographic studies along the Chilean Pacific coast have focused on benthic organisms and oceanographic conditions are considered the main factors influencing their distributions. Herein we examined the geographic distribution of pelagic barnacles of the family Lepadidae collected from floating macroalgae at seven sampling areas between 23 and $50^{\circ} \mathrm{S}$. Four species were encountered and they are briefly described herein. The most abundant northern species was Lepas anatifera, and it diminished in abundance towards the south $\left(33^{\circ} \mathrm{S}\right)$. Moreover, this species was not found in waters with a sea surface temperature (SST) of less than $\sim 18{ }^{\circ} \mathrm{C}$. Lepas australis, primarily a circumpolar West Wind Drift species, diminished in abundance towards the north $\left(33^{\circ} \mathrm{S}\right)$. This species was restricted to waters of $<18{ }^{\circ} \mathrm{C} \mathrm{SST}$. A third species, L. pectinata, was encountered throughout almost the entire study area, but it was most abundant between 29 and $33^{\circ} \mathrm{S}$. The fourth species, Dosima fascicularis, was only found at two sampling areas, namely at $27^{\circ} \mathrm{S}$ and $33^{\circ} \mathrm{S}$, and this is the first record of this species from the central coast of Chile. The distributional pattern of the pelagic barnacles found herein corresponds to the three main zoogeographic regions as revealed by the majority of previous studies based on littoral organisms: the northern Peru-Chilean Province, the southern Magellanic Province, and the central Chilean Transition Zone where the two provinces overlap. Even though the present study only considers four species of pelagic barnacles, the results support the hypotheses on the importance of oceanographic conditions (in particular SST) in determining the zoogeographic patterns along the south east Pacific coast of Chile.
\end{abstract}

Key words: zoogeography, Lepas, oceanography, pelagic, Cirripedia.

\section{RESUMEN}

La mayoría de los estudios de zoogeografía a lo largo de la costa chilena del Pacífico sur este se han enfocado en organismos bentónicos y las condiciones oceanográficas se sugieren como factores principales que modulan su distribución. Aquí examinamos la distribución geográfica de especies de cirripedios pelágicos de la familia Lepadidae, asociadas a macroalgas flotando a la deriva, en siete áreas de muestreo entre los 23 y $50^{\circ} \mathrm{S}$. Se encontraron cuatro especies de cirripedios lepádidos y cada una se describe brevemente. La especie del norte más abundantes fue Lepas anatifera y disminuye su abundancia hacia el sur $\left(33^{\circ} \mathrm{S}\right)$. Además, esta especie no se encontró en temperatura superficial del mar (SST) inferior a $\sim 18{ }^{\circ} \mathrm{C}$. Lepas australis, que posee una distribución circumpolar, atenúa su abundancia hacia el norte $\left(33^{\circ} \mathrm{S}\right)$. Esta especie se restringe a SST $<18{ }^{\circ} \mathrm{C}$. La tercera especie, L. pectinata se extiende en la mayor parte del área de estudio, pero posee su mayor abundancia relativa en el área central, entre 29 y $33^{\circ} \mathrm{S}$. La cuarta especie, Dosima fascicularis, solo se encontró en dos lugares de muestreo, en 27 y $33^{\circ} \mathrm{S}$, y es el primer registro para la costa central de Chile. El patrón de distribución de estas especies de cirripedios pelágicos corresponde a las principales zonas geográficas reveladas por la mayoría de estudios previos basados en organismos bentónicos: la Provincia Peruano-Chilena del Norte, la Provincia Magallánica del Sur y una Zona Central de Transición, donde las dos provincias se sobreponen. A pesar que el presente estudio solo considera cuatro especies de cirripedios pelágicos, nuestros resultados apoyan la hipótesis de la importancia de las condiciones oceanográficas (en particular: SST) en la modulación del patrón zoogeográfico a lo largo de la costa sur este del Pacífico, Chile.

Palabras clave: zoogeografía, Lepas, oceanografía, pelágico, cirripedios. 


\section{INTRODUCTION}

The majority of biogeographic studies along the south east Pacific coast of Chile indicate the presence of three biogeographical zones (e.g., Knox 1960, Lancellotti \& Vásquez 1999, 2000, Camus 2001, Thiel 2002; but see also Hernández et al. 2005). In general, there is evidence that the northern biota, with its temperate characteristics, extends southwards while the austral biota extends northwards, and both overlap in a central zone. In a review of various biogeographic studies, Camus (2001) suggested the following limits for the south east Pacific: (i) the Peruvian Province north of $30^{\circ} \mathrm{S}$, (ii) the Magellanic Province south of 41$43^{\circ} \mathrm{S}$, and (iii) the intermediate area in the central Chilean region, where the two first provinces overlap. Additionally, it has been discussed that the exact limit for each zone can vary depending on the number of taxa considered in the respective studies (Lancellotti \& Vásquez 2000, Camus 2001) or the prevalent oceanographic conditions during the sampling period (Thiel 2002, Escribano et al. 2003).

Most zoogeographic studies along the SE Pacific coast have focused on littoral organisms (primarily benthic invertebrates), and oceanographic conditions have been suggested as the main factors influencing species dispersal (Knox 1960, Menzies 1962, Lancellotti \& Vásquez 1999, 2000, Ojeda et al. 2000, and references in Camus 2001). In particular, it has been inferred that the latitudinal gradient of sea surface temperature (SST) along the Chilean coast is responsible for the distribution of many littoral and benthic organisms (Lancellotti \& Vásquez 1999, 2000, Astorga et al. 2003, Rivadeneira \& Fernández 2005). While relatively consistent biogeographic patterns are emerging, the driving forces behind these patterns are not very well known. SST may act directly on adult organisms in benthic habitats, or it may affect transport and survival of planktonic dispersal stages. If biogeographic patterns are dependent on water column processes, we could expect similar patterns for planktonic organisms as have been revealed for littoral benthic organisms.

While most studies along the Pacific coast of Chile have focused on the latitudinal distribution of littoral benthos, there are also a few studies on pelagic species. Fagetti (1968) reported on three groups of species of Chilean Chaetognatha; a northern group consisting of tropical-equatorial species, a southern group consisting of sub-Antarctic species, and a central group of species. The author mentioned a key species within each of the three groups that acted as a bio-indicator for each of the different water masses (SST and salinity). A northern species is replaced by a southern species at $30^{\circ} \mathrm{S}$, whereas another northern species ranges southward to $38^{\circ} \mathrm{S}$. Antezana (1981) identified four groups of Euphausiacea for the south east Pacific, and included the geographic information of chaetognaths, medusae and calanoid copepod fauna. This author distinguished two provinces along the Pacific coast of Chile, a northern PeruvianChilean province and a southern Magellanic province, separated by a transitional zone between $38^{\circ} \mathrm{S}$ at $42^{\circ} \mathrm{S}$. As the principal cause for this pelagic faunas distribution pattern he suggested that the northern limit of intrusion of subantarctic waters in the Humboldt Current lies between about 37 and $38^{\circ} \mathrm{S}$. Similarly, in a recent synthesis of the pelagic fauna, Escribano et al. (2003) suggested three zoogeographical regions along the Chilean cost; Northern Upwelling Region (NUR, north of $30^{\circ} \mathrm{S}$ ), Central/South Upwelling Region (CSUR, 30 to $40^{\circ} \mathrm{S}$ ) and an Austral Fjord Region (AFR, south of $40^{\circ} \mathrm{S}$ ). These authors found similarities in phyto- and zooplankton composition between NUR and CSUR, but mentioned that "physical processes may be more important in regulating pelagic populations in the CSUR than in the NUR, where biological interactions seem to play a greater role". Thus, pelagic organisms indeed appear to display a very similar distributional pattern as many benthic organisms. In order to verify whether this pattern holds for other organisms, herein we examined the distribution of pelagic goose barnacles.

All barnacles of the family Lepadidae (goose barnacles) are pelagic, commonly found associated with floating objects, e.g., ships, buoys, wood, animals, marine debris and macroalgae, and only members of one genus (Dosima) can produce a float of their own (Skerman 1958, Cheng \& Lewin 1976, Arnbom \& Lundberg 1995, Minchin 1996, Gollasch 2002, Sano et al. 2003). Some authors 
suggested that the geographic distribution of theses barnacles is restricted to particular oceanographic conditions (e.g., species-specific SST) (Zevina \& Memmi 1981, Moyse 1987, Green et al. 1994).

In the Southern Hemisphere goose barnacles are found abundantly on rafts of two species of floating macroalgae, Macrocystis spp. (C. Agardh, 1820) and Durvillaea antarctica (Hariot 1892), (Helmuth et al. 1994, Smith \& Bayliss-Smith 1998, Thiel \& Gutow 2005). The time that detached macroalgae survive on the sea surface before sinking (several weeks to months) is sufficiently long for larvae of goose barnacles to settle, grow and achieve sexual maturity (Skerman 1958, Green et al. 1994, Smith \& Bayliss-Smith 1998, Hobday 2000a).

In this study we present brief descriptions of the goose barnacles found on floating Macrocystis spp. and D. antarctica along the Chilean Pacific coast. Additionally, we describe the distributional pattern of these pelagic barnacles and compare it with the biogeography reported for benthic marine organisms. We expected that if the actual distribution of littoral fauna is determined by recent oceanographic processes, the distribution pattern of pelagic organisms (such as goose barnacles) should match that of the littoral fauna.

\section{MATERIAL AND METHODS}

During austral summer 2002 (January-March) we carried out nine surveys along the south east Pacific coast of Chile, between $\sim 18$ and $\sim 50^{\circ} \mathrm{S}$. For the surveys we utilized medium-sized $(\sim 15$ $m$ total length) fishing boats or research vessels. The ship track led westward for $\sim 50$ $\mathrm{km}$, turning southwards for $\sim 15 \mathrm{~km}$ before returning directly to the port. Each hour we recorded the SST, thus obtaining $\sim 12$ measurements for each sampling area, except for the location close to "Isla Madre de Dios" $\left(\sim 50^{\circ} \mathrm{S}\right.$, where we could only take one measurement due to foul weather). During navigation we surveyed the sea surface for floating Macrocystis spp. and Durvillaea antarctica. Samples were only taken at seven areas (Table 1), because no floating macroalgae were detected at the two northernmost locations (Arica and Iquique). The number of samples varied for each sampling area between six (in Mejillones) and 15 (in Concepción and "Isla Madre de Dios") (Table 1). At most sampling areas, floating macroalgae were collected between 5 to $50 \mathrm{~km}$ out from the coast, except for "Isla Madre de Dios" where macroalgae were sampled 2 to $4 \mathrm{~km}$ off the mouth of a large oceanic channel.

Number of samples of Macrocystis spp. and Durvillaea antarctica, Sea Surface Temperatures (SST), number of samples with lepadomorph cirriped associates (samples w/Lepas) and relative percentage of adult barnacles versus cyprids by locality. Samples with Lepas include samples only with cyprids larvae in parenthesis samples with adult Lepas

Temperatura superficial del mar (SST), número de muestras de Macrocystis spp. y Durvillaea antarctica, número de muestras que presentaban cirripedios lepadomorfos asociados (samples w/Lepas) y porcentaje relativo de cirripedios adultos versus cypris recién asentadas por localidad. Muestras con Lepas incluye muestras solo con larvas cypris, en paréntesis muestras con Lepas adultas identificables

\begin{tabular}{ccccccc}
\hline Site & Latitude & SST $\left({ }^{\circ} \mathrm{C}\right)$ & Samples of \\
Mean $\pm \mathrm{SD}$ & $\begin{array}{c}\text { Macrocystis } \\
\text { spp. }\end{array}$ & $\begin{array}{c}\text { Samples of } \\
\text { D. antarctica }\end{array}$ & $\begin{array}{c}\text { Samples } \\
\text { w/Lepas }\end{array}$ & $\begin{array}{c}\text { Total } \\
\text { Lepas }\end{array}$ & $\begin{array}{c}\text { Total } \\
\text { cyprids }\end{array}$ & $\begin{array}{c}\text { Percentage } \\
\text { of cyprids } \\
\text { of Lepas }\end{array}$ \\
\hline
\end{tabular}

\begin{tabular}{|c|c|c|c|c|c|c|c|c|}
\hline Arica & $18^{\circ} \mathrm{S}$ & $21.1 \pm 2.7$ & - & - & - & - & - & - \\
\hline Iquique & $20^{\circ} \mathrm{S}$ & $19.4 \pm 2.1$ & - & - & - & - & - & - \\
\hline Mejillones & $23^{\circ} \mathrm{S}$ & $21.2 \pm 1.9$ & 6 & - & 6 & 3,313 & 1,441 & 30.3 \\
\hline Caldera & $27^{\circ} \mathrm{S}$ & $18.8 \pm 2.0$ & 7 & - & 7 & 12,569 & 783 & 5.9 \\
\hline Coquimbo & $29^{\circ} \mathrm{S}$ & $16.7 \pm 1.0$ & 9 & 1 & $8(2)$ & 18 & 1,063 & 98.3 \\
\hline San Antonio & $33^{\circ} \mathrm{S}$ & $18.2 \pm 1.0$ & 6 & 6 & $12(10)$ & 7,197 & 8,171 & 53.2 \\
\hline Concepción & $36^{\circ} \mathrm{S}$ & $14.5 \pm 0.9$ & 11 & 4 & $15(13)$ & 33,286 & 13,151 & 28.3 \\
\hline Ancud & $41^{\circ} \mathrm{S}$ & $13.2 \pm 0.5$ & 6 & 5 & 11 & 9,949 & 8,061 & 44.8 \\
\hline Isla Madre de Dios & $50^{\circ} \mathrm{S}$ & 9.2 & 5 & 10 & $9(5)$ & 91 & 230 & 71.7 \\
\hline
\end{tabular}


When floating macroalgae were encountered, randomly selected macroalgae were collected with the aid of a dip net (ring diameter $\mathrm{r}=60 \mathrm{~cm}$, mesh size of funnel $=3$ $\mathrm{mm}$, mesh size of cod end $=0.5 \mathrm{~mm}$, see Hinojosa et al. $2003^{1}$ ). We collected individual algal patches $<60 \mathrm{~cm}$ diameter, directly from the vessel. In the case of algal patches $>2 \mathrm{~m}$ diameter, a diver cut random samples from the whole patch that were immediately placed in the mesh bag $(0.5 \mathrm{~mm}$ mesh). All samples were placed in plastic bags and preserved in $5 \%$ formalin. In the laboratory, samples were rinsed thoroughly with freshwater over a sieve $(0.25 \mathrm{~mm})$, and all epibionts, including goose barnacles, were carefully removed. Barnacles were transferred to $70 \%$ alcohol and later identified under a dissecting microscope. Total abundance (number of individuals) per sample was recorded in order to calculate the relative abundance (in percentage). Herein, we present relative proportions rather than absolute values (abundance per gram of macroalgae) because the abundances of goose barnacles is influenced by the floating time of macroalgae. The relative abundances of goose barnacles associated with Macrocystis spp. and Durvillaea antarctica samples were treated separately in order to account for the possibility of a species-specific association (one species of Lepas settling preferentially on either species of macroalgae).

In order to examine the latitudinal distribution pattern of the studied goose barnacles, we conducted a non-metric multidimensional scaling ordination (nMDS; Field et al. 1982, Clarke 1993) using the BrayCurtis dissimilarity measure of relative species abundance on each of the two species of floating algae. Since the comparative analysis revealed no significant differences in the composition of Lepas spp. between the two algal species (see below), we pooled all samples to calculate relative abundance per locality for purposes of graphic presentation.

\footnotetext{
1 HINOJOSA I, ER GONZÁLEZ, P UGALDE, N VALDIVIA, E MACAYA \& M THIEL (2003) Distribución y abundancia de macroalgas flotando a la deriva y su fauna peracárida asociada a en los canales de la XI Región, Chile. Resultados crucero CIMAR 8 fiordos: 109-120. Comité Oceanográfico Nacional, Chile.
}

\section{RESULTS}

The majority of the collected macroalgae harbored barnacles of the family Lepadidae (goose barnacles). The lowest percentage of samples with goose barnacles was found near Isla Madre de Dios (60.0\%, Table 1). In total, $67.0 \%$ of the goose barnacles were identified to species. All others were noted as cyprids since calcareous plates were missing. The relative percentage of cyprids was highest in the sampling area off Coquimbo (98.4\%, Table 1). In total, four species of goose barnacles associated to floating macroalgae were identified, for which a brief morphological description is presented in the following. The quantity and deposition number for the voucher specimens sent to the Museo Nacional de Historia Natural de Chile (MNHN) is noted following the description of each species.

\section{Description of the goose barnacles from the Chilean Pacific coast}

In general the species of the family Lepadidae possess a capitulum covered by five calcareous plates and a naked peduncle. Most species feature one or more characteristic filamentary appendages on or near the pedicel of the first cirrus (Fig. 1). All species represented herein can be distinguished using the relationship, form and texture of these plates as well as by the number and the relative length of the filamentary appendages (Fig. 1 and 3).

\section{Lepas anatifera Linnaeus, 1767}

General description: the carina is generally smooth or sometimes barbed, usually sharply bifurcated near the basal umbo; scutum is smooth, sometimes with concentric rays radiating up from the umbo; right scutum with one internal umbonal tooth, independent of developmental status although some individuals have a more pronounced than others; tergum is a little convex and obliquely quadrangular (Darwin 1852, Newman \& Ross 1971) (Fig. $2 \mathrm{~A})$. With two filamentary appendages on each side of the body, a short one near the basis of the first cirrus and a large one nearby on the prosoma (Fig. 3A). Lepas anatifera shows a great similarity with $L$. australis. However, it 
can be distinguished from the latter by three main characteristics: (1) the presence of a single internal umbonal tooth on the right scutum, (2) the form of the carina is more tapered and shows bifurcation on the base and (3) the filamentary appendage of the prosoma is relatively large (relationship between length of scutum and filamentary appendage differs significantly between $L$. anatifera and $L$. australis; $\mathrm{F}=62.286 ; \mathrm{DF}=1,20 ; \mathrm{P}<0.001$, Fig. 3). Additionally, this filamentary appendage is comparatively more conspicuous in L. anatifera than in L. australis.

Inhabited substrata: Lepas anatifera has been found associated with diverse animals and floating objects such as e.g., macroalgae (Hobday 2000b), bottles (Young 1990), boats, buoys (Nilsson-Cantell 1957), wood (Minchin 1996), turtles (Kitsos et al. 2003) and even fish (Zevina \& Memmi 1981). Voucher specimens, ten individuals deposited in the MNHN of Chile: MNHNCL CIRR - Nº11548.
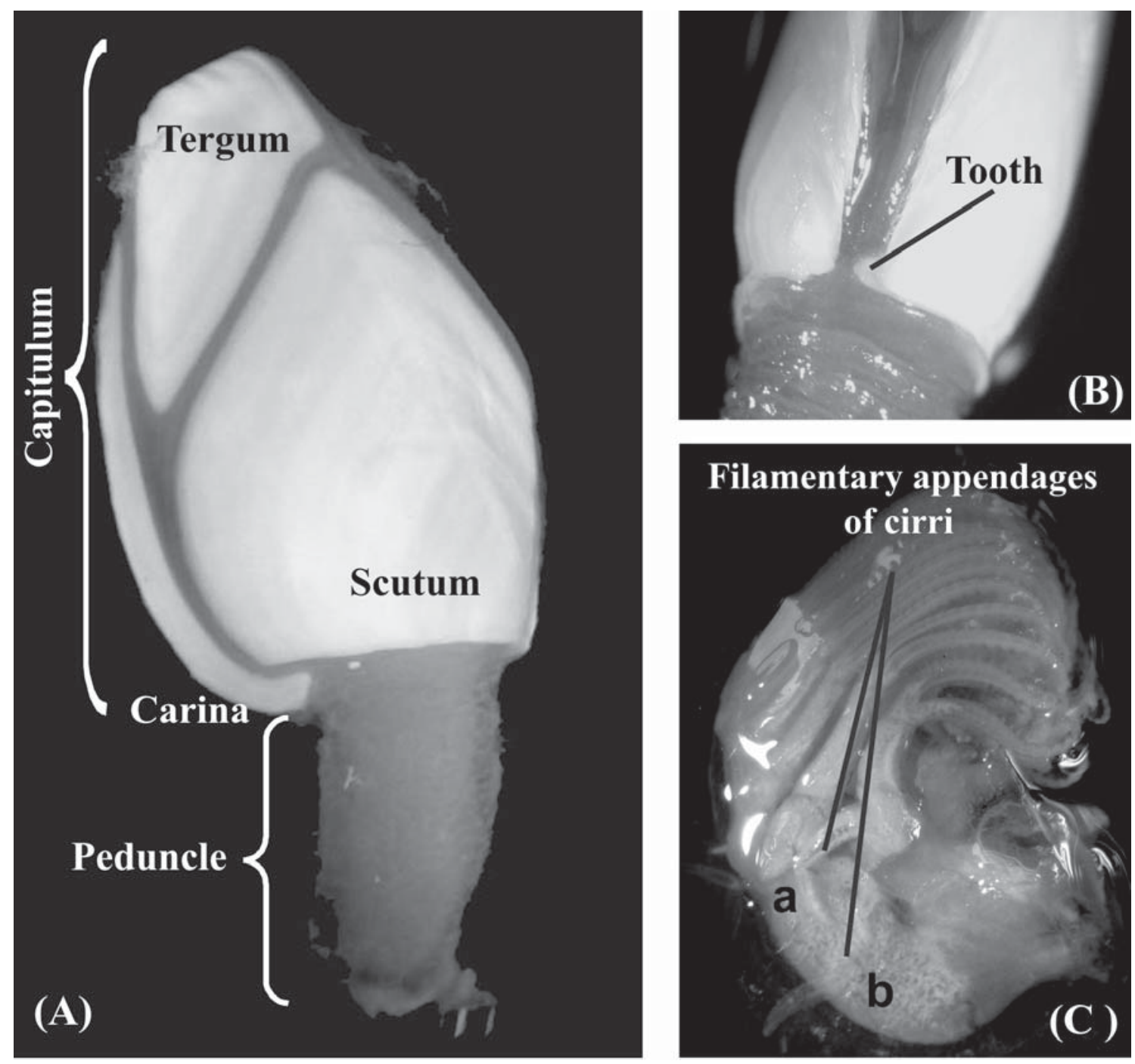

Fig. 1: Characteristics of Lepas spp.: (A) body divisions and calcareous plates referred to in the text, (B) Internal umbonal tooth of scutum, and (C) Filamentary appendages: (a) of the coxa of cirrus I and (b) the prosoma.

Características de Lepas spp.: (A) división del cuerpo y placas calcáreas indicadas en el texto, (B) Diente umbonal interno del scutum, (C) Apéndices filamentosos de los cirros: (a) apéndice de la coxa del primer cirro y (b) apéndice del prosoma. 
General description: the carina is generally smooth, basal fork often broadly rounded, the apex not extending up between the terga; scutum smooth and flat, triangular but can be also quadrangular, both scuta have an internal umbonal tooth, the size of the teeth is variable and independent from the developmental status of individuals; Tergum, triangular, smooth and sometimes convex (Fig. 2B) (Darwin 1852, Newman \& Ross 1971, Arnaud 1973, Foster 1978). With two filamentary appendages on each side of the body; one is located at the base of the first cirrus and the other near the prosoma. As noted above, this species is very similar to $L$. anatifera. However, L. australis generally has an internal umbonal tooth on each scutum, the carina is wider and often proportionately shorter, and the filamentary appendage on each side of the prosoma is comparatively short (Darwin 1852, Foster 1978) (Fig. 3).

Inhabited substrata: this species has been reported on floating macroalgae (Darwin 1852, Nilsson-Cantell 1957, Arnaud 1973, Zevina \& Memmi 1981, Helmuth et al. 1994), volcanic pumice (Newman \& Ross 1971), plastics (Barnes \& Milner 2005) and on marine sea elephants (Mirounga leonia, Arnbom \& Lundberg 1995, Barnes et al. 2004). Voucher specimens, ten individuals deposited in the MNHN of Chile: MNHNCL CIRR - N${ }^{\circ} 11549$.

\section{Lepas pectinata Spengler, 1793}

General description: the upper part of the carina is wide and gets slowly narrower bifurcating at the end, generally barbed; scutum almost triangular with radial furrows, often with spines; the right scutum with internal umbonal tooth; tergum almost triangular, radial furrowed, often with spines; both terga with a visible notch to receive the apex of the scutum; no space between scutum and tergum (Darwin 1852, Foster 1978, Young 1990) (Fig. 2C). Filamentary appendages reduced to a small protuberance at the base of the first cirrus.

Inhabited substrata: mainly associated with macroalgae and floating objects e.g. boats, buoys (Tsikhon-Lukanina et al. 1986), wood (Young 1990), tar pellets, plastics and volcanic pumice (Minchin 1996). Voucher specimens, ten individuals deposited in the MNHN of Chile: MNHNCL CIRR - N${ }^{\circ} 1550$.
General description: the genus Dosima can be easily distinguished from the genus Lepas by the distinct angle formed at the sub-central umbo of the carina, and the very thin and brittle plates (Young 1990). During its development this species changes considerably in form; carina smooth and thin, the form is very different from the previous species, the base is almost round and not imbedded in the membrane, in the medium part (umbo) with an angle of 100 degrees; scutum smooth and thin, also with a very different form as in comparison to all other species, it is separated from the other plates, no umbonal tooth is present; tergum is smooth and thin, with three angles, also flat (Darwin 1852, Newman \& Ross 1971, Foster 1978, Young 1990) (Fig. 2D). Five filamentary appendages located at the base of the cirri on each side of the body.

Inhabited substrata: Dosima fascicularis is mainly found associated on small plastic fragments and tar pellets (Minchin 1996) or simply without substrate (Zevina \& Memmi 1981). The species gains buoyancy due to the secretion of gas bubbles into a foam-float at the base of the peduncle (Darwin 1852, Boetius 1952-1953, Newman \& Ross 1971, Zevina \& Memmi 1981, Minchin 1996). Voucher specimens, two individuals deposited in the MNHN of Chile: MNHNCL CIRR - N 11551.

\section{Distribution of goose barnacles along the Chi- lean Pacific coast}

We found a similar faunal composition of goose barnacles on the two species of floating macroalgae (Macrocystis spp. and Durvillaea antarctica) from the respective sampling areas. The total abundances of Lepas spp. were similar on the two collected macroalgae with the highest abundances being found at Concepción (Table 2). Lowest total abundances were recorded in Coquimbo and Isla Madre de Dios (Table 2). A distinct distribution pattern of the assemblages of goose barnacles was observed along the Chilean coast, showing a strong break between San Antonio and Concepción (Fig. 4). In both areas, the relative abundances of barnacles growing on Durvillaea antarctica showed similarities with that on Macrocystis spp. in the sampling areas immediately to the north, which contrasts with the 

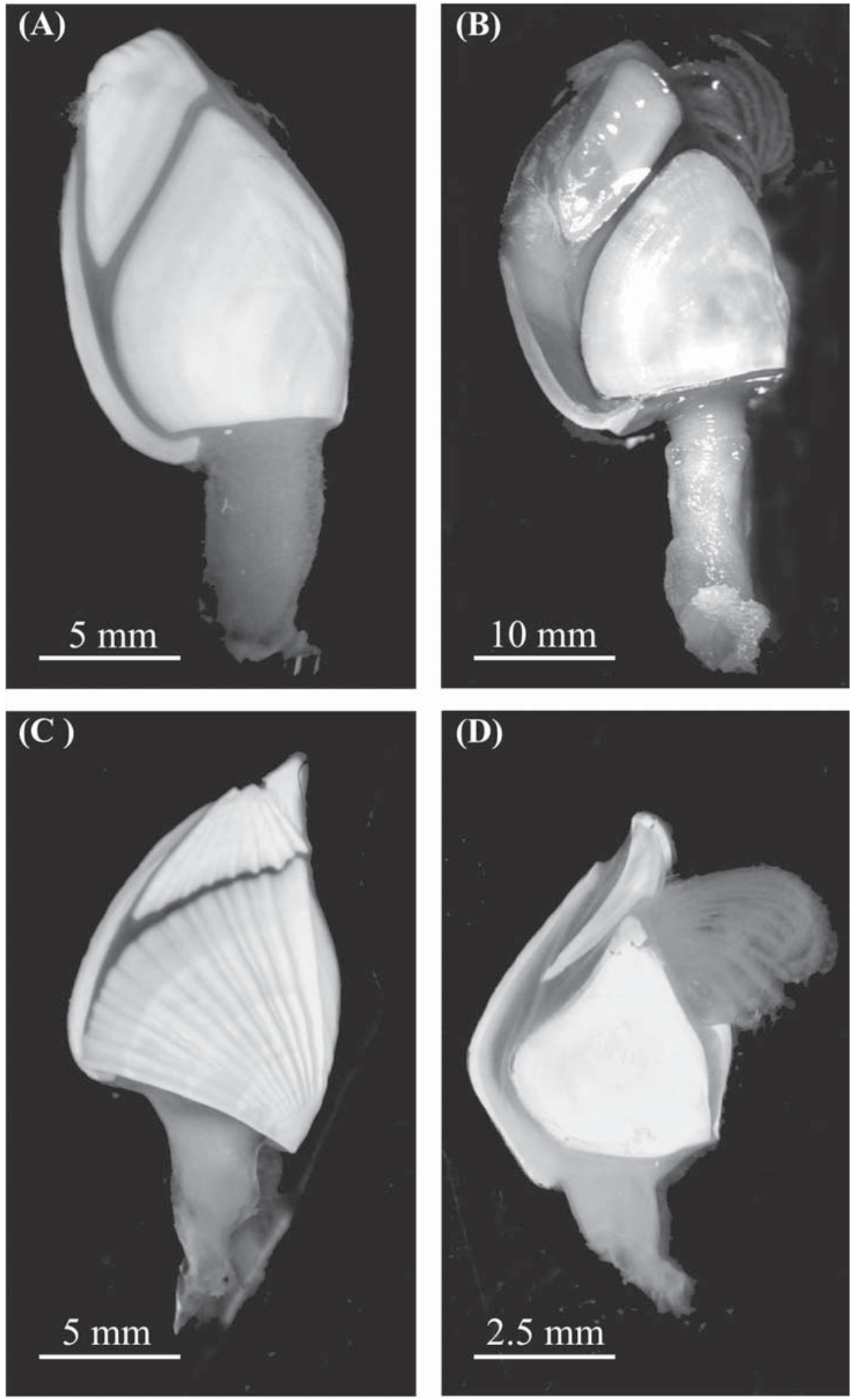

Fig. 2: Images of the four species found associated with floating seaweed from the study area: (A) Lepas anatifera, (B) Lepas australis, (C) Lepas pectinata, and (D) Dosima fascicularis.

Fotografía de las cuatro especies encontradas asociadas a macroalgas flotando a la deriva en el área de estudio. (A) Lepas anatifera, (B) Lepas australis, (C) Lepas pectinata y (D) Dosima fascicularis. 

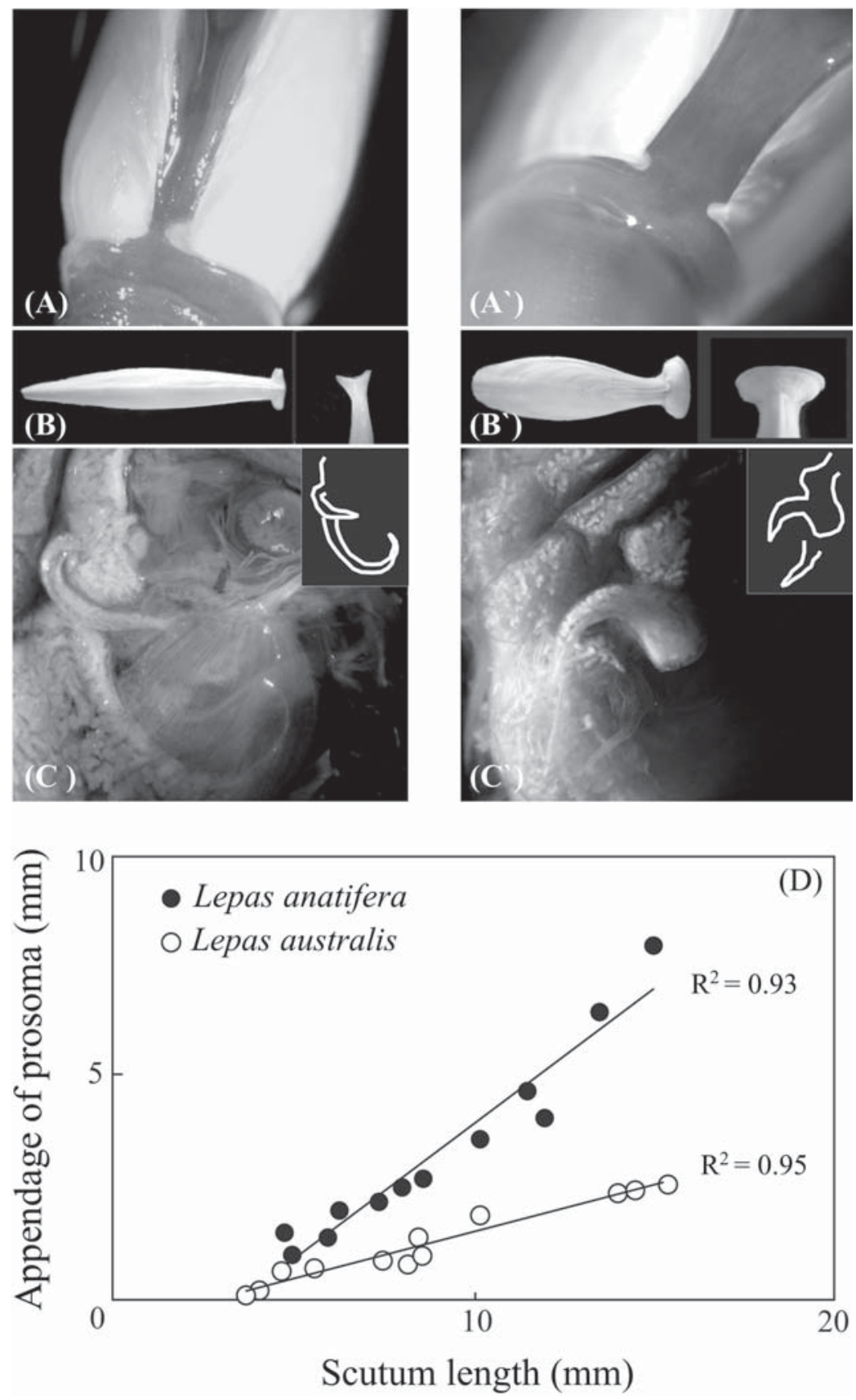

Fig. 3: Images showing the main differences between Lepas anatifera and Lepas australis: (A and A'), internal umbonal teeth of the scutum, respectively, (B and B') Shape of the carina and details of its base, respectively, (C and C') Filamentary appendages of cirrus I and the prosoma, respectively, and (D) Regressions involving the relationship between the lengths of the scutum and of the filamentary appendages of the prosoma for each species $(\mathrm{F}=138.4, \mathrm{DF}=1,10, \mathrm{P}<0.001$ for $L$. anatifera and $\mathrm{F}=208.8, \mathrm{DF}=1,10, \mathrm{P}<0.001$ for $L$. australis; for each regression analysis; slopes are significantly different, $\mathrm{F}=62.286, \mathrm{DF}=1,20, \mathrm{P}<0.001)$.

Fotografías y gráfico de las principales diferencias entre Lepas anatifera y Lepas australis: (A y A') Diente umbonal interno del o los scutum respectivamente. (B y B') Forma de la carina y detalle de su base, respectivamente. (C y C') Apéndices de los cirros y esquema de los mismos respectivamente. (D) Análisis de regresión entre la longitud del scutum y longitud del apéndice del prosoma para cada una de las especies de Lepas (F = 138,4; GL = 1,10; P < 0,001 para $L$. anatifera y $\mathrm{F}=208,8 ; \mathrm{GL}=1,10 ; \mathrm{P}<0,001$ para L. australis; para cada análisis de regresión; las pendientes son significativamente diferentes $\mathrm{F}=62,286 ; \mathrm{DF}=1,20 ; \mathrm{P}<0,001)$. 
TABLE 2

Total abundance of different Lepas spp. species associated with macroalgaes Macrocystis spp. y Durvillaea antarctica in each sampling area

Abundancia total de las distintas especies de Lepas spp. asociadas a las macroalgas Macrocystis spp. y Durvillaea antarctica en cada localidad muestreada

\begin{tabular}{|c|c|c|c|c|c|c|}
\hline \multirow[t]{2}{*}{ Sampling area } & \multicolumn{2}{|c|}{ Lepas anatifera } & \multicolumn{2}{|c|}{ Lepas pectinata } & \multicolumn{2}{|c|}{ Lepas australis } \\
\hline & Macrocystis spp. & D. antarctica & Macrocystis spp. & D. antarctica & Macrocystis spp. & D. antarctica \\
\hline Mejillones & 3,176 & - & 137 & - & 0 & - \\
\hline Caldera & 10,025 & - & 2,544 & - & 0 & - \\
\hline Coquimbo & 5 & 0 & 13 & 0 & 0 & 0 \\
\hline San Antonio & 374 & 867 & 3,901 & 1,988 & 67 & 0 \\
\hline Concepción & 0 & 0 & 6,700 & 5,487 & 15,905 & 5,194 \\
\hline Ancud & 0 & 0 & 639 & 58 & 7,975 & 1,277 \\
\hline Isla Madre de Dios & 0 & 0 & 0 & 0 & 51 & 40 \\
\hline
\end{tabular}

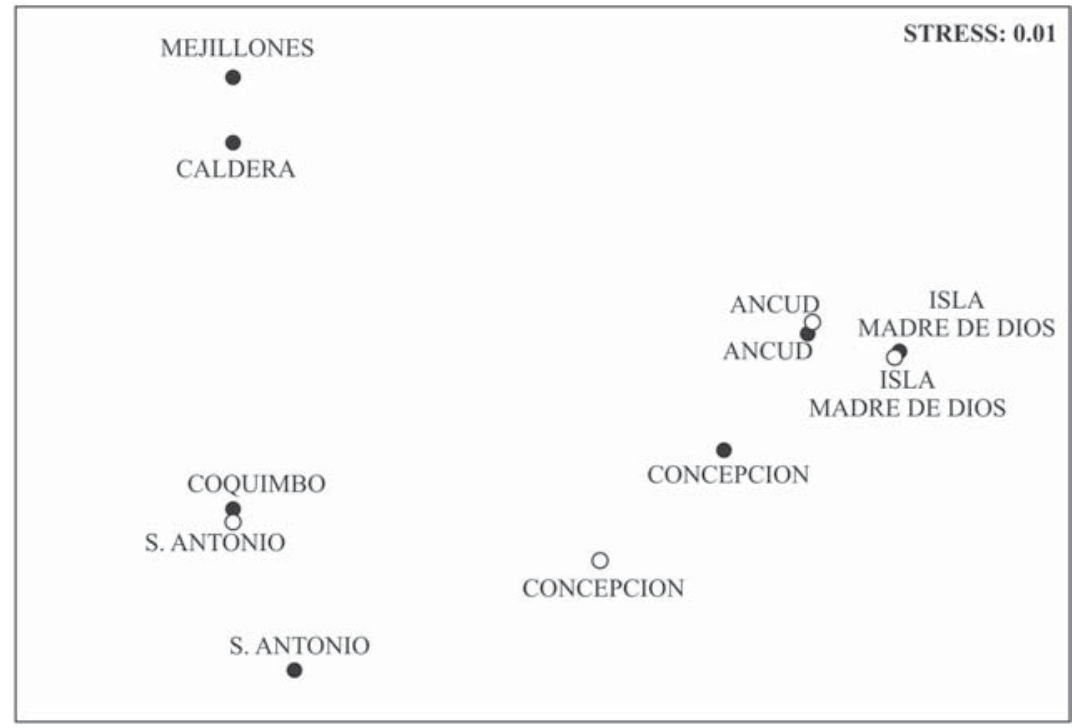

Fig. 4: nMDS results for comparisons of relative abundances of Lepas spp. species for each localities associated with Macrocystis spp. (black dots) and Durvillaea antarctica (gray dots).

Prueba nMDS para la abundancias relativas de las especies de Lepas spp. en cada localidad asociadas tanto a macroalgas Macrocystis spp. (círculos negros) y Durvillaea antarctica (círculos grises).

southern sampling areas where no differences in the barnacle assemblages from both algal species were observed.

Lepas anatifera was mainly distributed in the northern region of the study area, with highest relative abundances in Mejillones $\left(23^{\circ} \mathrm{S}\right)$ and Caldera $\left(27^{\circ} \mathrm{S}\right)$ of 95.9 and $79.6 \%$, respectively, but declining in abundance before dropping out at $33^{\circ} \mathrm{S}$ (Fig. 5). In both locations of abundance, the average SST fluctuated between 18.8 and
$21.2{ }^{\circ} \mathrm{C}$ (Table 1). In contrast, L. australis showed a southern distribution, with declining abundances from "Isla Madre de Dios" $\left(50^{\circ} \mathrm{S}\right.$, $100 \%$ ) north to Ancud ( $41^{\circ} \mathrm{S}, 92.7 \%$ ) and Concepción ( $36^{\circ} \mathrm{S}, 63.8 \%$ ), before dropping out at $\sim 33^{\circ} \mathrm{S}$ (see Fig. 5) where the average SST fluctuated between 9.6 and $14.5^{\circ} \mathrm{C}$ (Table 1). Lepas pectinata was encountered at all sampling areas except for "Isla Madre de Dios", with the highest relative abundance in the central region, 
off Coquimbo ( $\left.29^{\circ} \mathrm{S}, 72.2 \%\right)$ and San Antonio $\left(33^{\circ} \mathrm{S}, 81.8 \%\right)$ (Fig. 5), where the average SST varied between 16.7 and $18.2{ }^{\circ} \mathrm{C}$ (Table 1). Dosima fascicularis found herein is the first definite record for the SE-Pacific coast. This species was only detected at two sampling areas, namely Caldera $\left(27^{\circ} \mathrm{S}, 0.2 \%, 27\right.$ individuals) and San Antonio $\left(33^{\circ} \mathrm{S}, 0.01 \%\right.$, only one individual). In general, in the present study we identify a northern zone dominated by $L$. anatifera, a central zone where L. pectinata was most abundant and a southern zone where $L$. australis showed the highest relative abundance.
The described distribution pattern of Lepas spp. along the Chilean coast fits well with the global distribution of the studied species (Fig. 6). In general, we found $L$. anatifera in highest proportion in warm waters corresponding to their general distribution in tropical and subtropical waters. In contrast, L. australis was found primarily in colder waters, which fits the reported pattern of this species in subantarctic water masses. Lepas pectinata was found in waters with intermediate SST, matching the published distributional records of this species (Fig. 6).
$\operatorname{SST}\left({ }^{\circ} \mathrm{C}\right)$

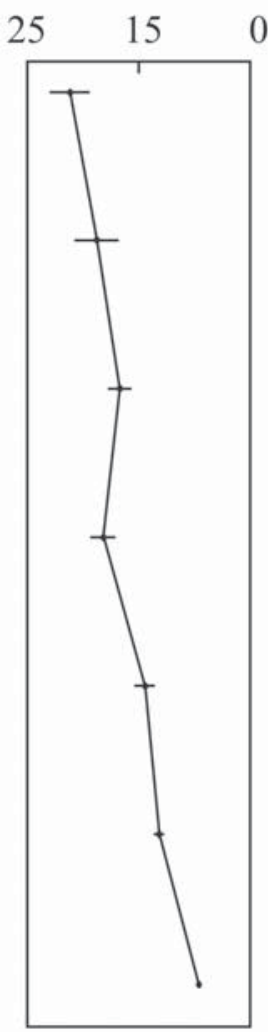

Relative Abundance (\%)

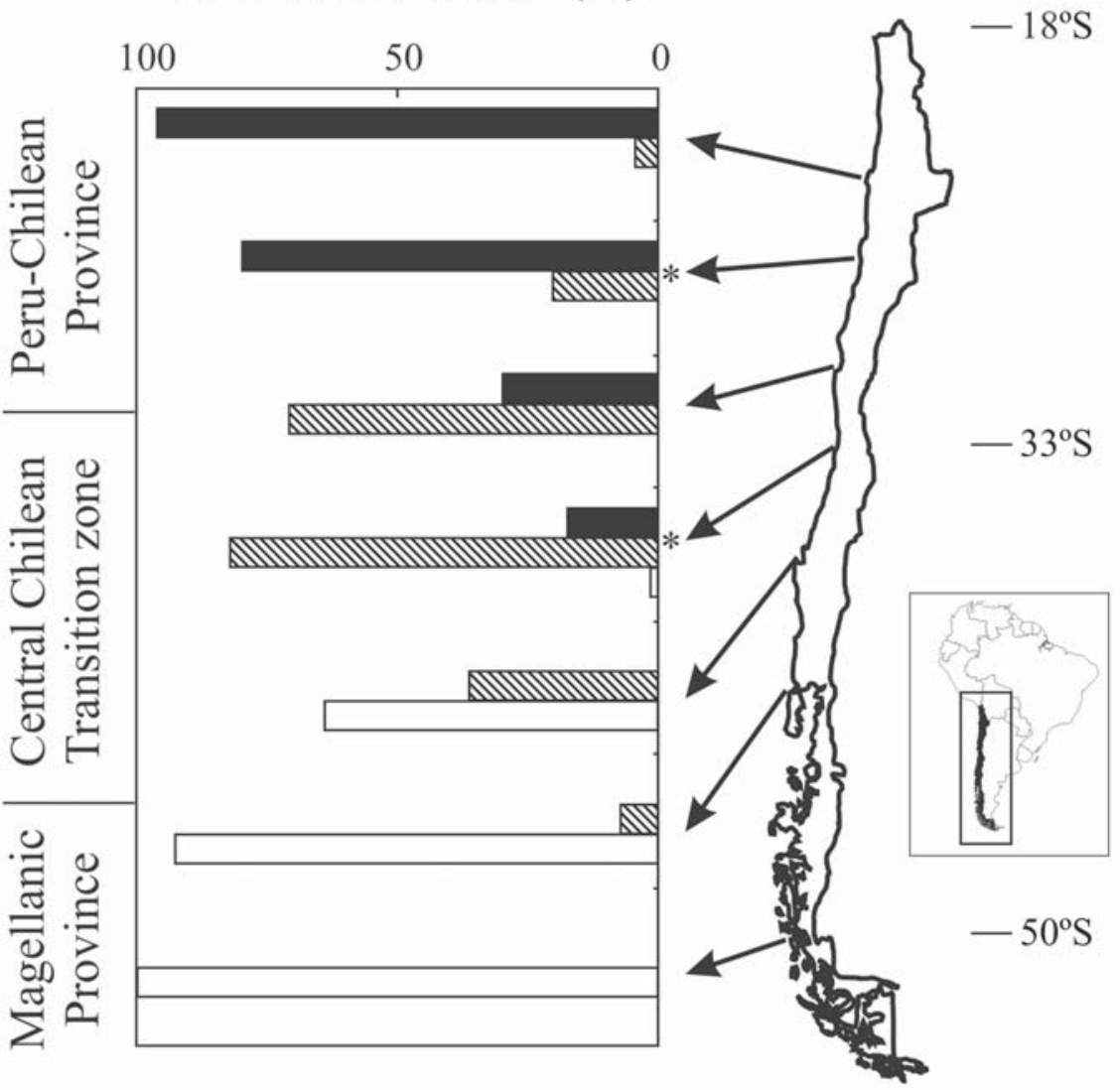

Lepas anatifera

Lepas pectinata

Lepas australis

Fig. 5: Relative abundances of the different species of Lepas spp. and sea surface temperatures along the south east Pacific coast of Chile; (*) indicates the localities where Dosima fascicularis was found.

Abundancia relativa de las diferentes especies de Lepas spp. y temperatura superficial del mar a lo largo de la costa sur este del océano Pacifico, Chile; (*) indica las localidades donde se encontró Dosima fascicularis. 


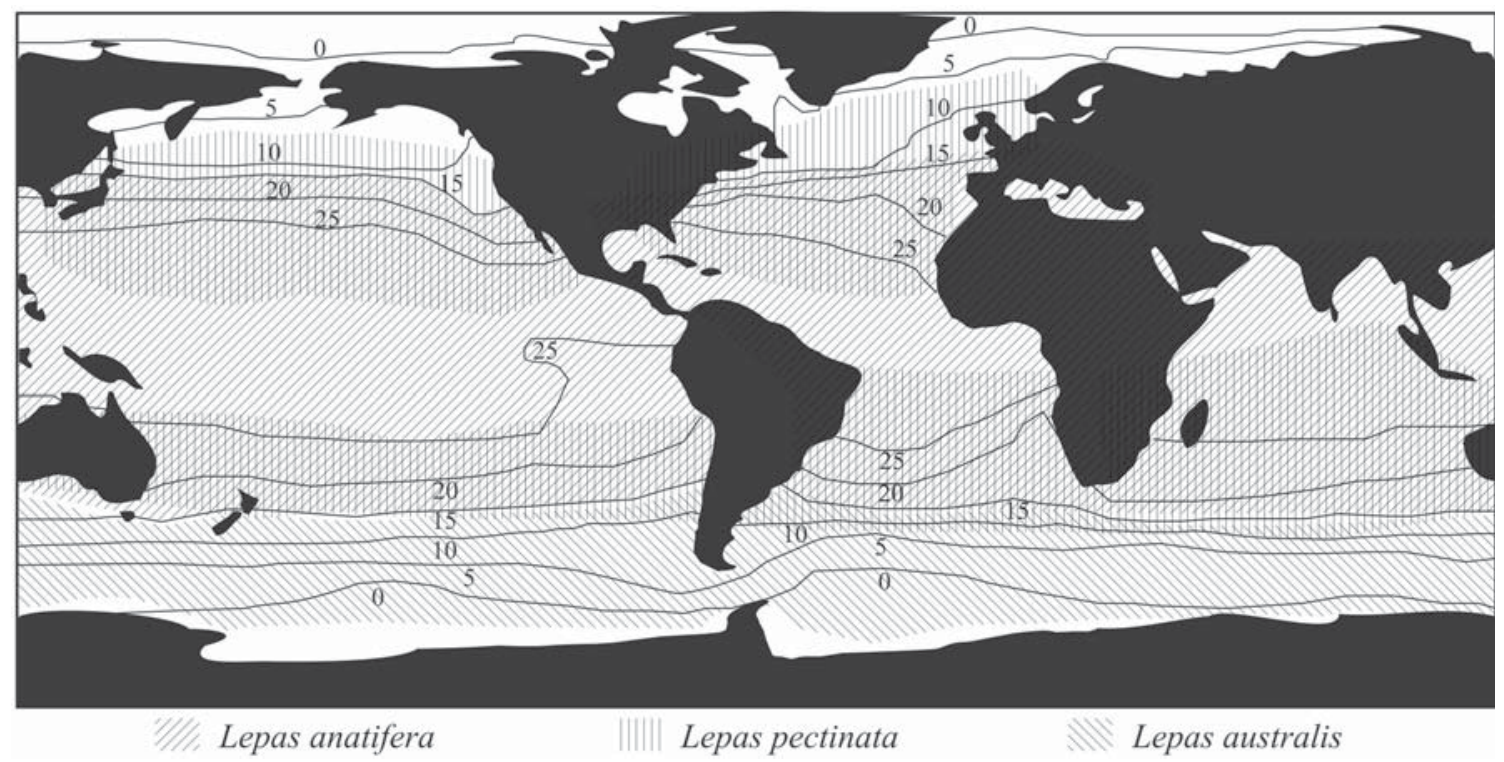

Fig. 6: Global distribution of the principal species of Lepas spp. found along the Chilean Pacific coast (distribution along the south east Pacific based on the present study). Lines and numbers represent SST isothermes. Information of the global distribution of Lepas spp. based on: Darwin (1852), Nilsson-Cantell (1938), Daniel (1955), Nilsson-Cantell (1957), Patel (1959), Gudmundsson \& Ingólfsson (1967), Newman \& Ross (1971), Newman (1972), Foster (1978), Zevina \& Memmi (1981), Young (1990), Il'in (1992), and Kitsos et al. (2003).

Distribución global de las principales especies de Lepas spp. encontradas en las costa chilena (distribución en el Pacífico SE basado en el presente estudio). Las líneas representan isotermas. La información de la distribución geográfica de las especies de Lepas spp. contenida en: Darwin (1852), Nilsson-Cantell (1938), Daniel (1955), Nilsson-Cantell (1957), Patel (1959), Gudmundsson \& Ingólfsson (1967), Newman \& Ross (1971), Newman (1972), Foster (1978), Zevina \& Memmi (1981), Young (1990), Il'in (1992), y Kitsos et al. (2003).

\section{DISCUSSION}

Pelagic barnacles along the south east Pacific coast of Chile

There exist only a few studies that examine the presence of pelagic barnacles along the Chilean coast. In a review of the barnacles of Chile, Nilsson-Cantell (1957) reported three species of pelagic barnacles from the family Lepadidae; namely, Lepas anatifera, $L$. pectinata and L. australis. In a previous study, this author had already reported these species for the Islands "Juan Fernández" (NilssonCantell 1929), suggesting they were the three most common lepadid species in Chilean waters. Memmi (1980) described what he considered a new species, Lepas annabellae, from the Chilean coast (Antofagasta, 2319' S, $71^{\circ} 01^{\prime} \mathrm{W}$ ). While it shows certain similarities with previously described varieties of $L$. australis, according to the author it does not present internal umbonal teeth on the scuta. Since the description of $L$. annabellae is only based on a single report of seven individuals, which were found stranded on the shore, the status of this species for the Chilean coast must be considered as uncertain.

In the present study four species of pelagic barnacles from the family Lepadidae were found on floating macroalgae (Lepas anatifera, L. pectinata, L. australis, and Dosima fascicularis). While the first three species were very common and had been previously reported (Nilsson-Cantell 1929, 1957), D. fascicularis is reported herein for the first time for the Chilean Pacific coast (see Newman \& Ross 1971 for a record near Cape Horn). This species was found in low abundances and only at two localities. Several authors mentioned that $D$. fascicularis is commonly associated with small plastic fragments (Boetius 1952-1953, Cheng \& Lewin 1976, Zevina \& Memmi 1981, Minchin 1996). Considering that the examined substrata 
in the present study were exclusively floating macroalgae, it could be possible that the abundance of D. fascicularis was underestimated, but it also cannot be ruled out that this species has recently increased in abundance, because of increasing availability of attachment substrata. Floating plastic fragments are abundant in the oceans and the high floating property of these items may favor dispersal of D. fascicularis and possibly of other species (Minchin 1996, Thiel et al. 2003, Barnes \& Milner 2005, Thiel \& Gutow 2005).

Floating Macrocystis spp. and Durvillaea antarctica with associated populations of goose barnacles may serve as a good indicator for local supply of their larvae because the floating period of these macroalgae is sufficiently long for larval settlement and growth (Skerman 1958, Green et al. 1994), but may not permit long distance dispersal of adults. In contrast, substrata that have the potential to remain afloat for long time periods (months or years) such as plastic litter or buoys, would have the chance to be dispersed to distant sites and thus far away from the place where initial settlement occurred. Thus, populations of goose barnacles on floating macroalgae may be a good indicator for local larval supply, whereas individuals on plastics (e.g., Barnes \& Milner 2005) and volcanic pumice (e.g., Bryan et al. 2004) may rather indicate distant larval pools.

Distribution of goose barnacles along the Chilean Pacific coast

Barnacles of the genus Lepas are reported to be widely distributed in the world's oceans, but most species have an optimum temperature range favoring reproduction and larval development (Fig. 6). Green et al. (1994) revealed that $L$. anatifera from the North Atlantic developed reproductive organs within $\sim 120$ days after settlement at SST between 10.2 to $18.4{ }^{\circ} \mathrm{C}$. The reproductive rates observed by these authors were low, possibly because penis activity is limited at temperatures $<19^{\circ} \mathrm{C} \mathrm{SST}$ (Patel 1959). Evans (1958) showed that at temperatures of $\sim 25^{\circ} \mathrm{C}$ this species can reach sexual maturity within $\sim 30$ days. Zevina \& Memmi (1981) mentioned that L. australis can be found in warmer waters, but the optimal water temperature for reproduction is between 5-15 ${ }^{\circ} \mathrm{C}$. In the Atlantic, Lepas pectinata is abundant at temperatures between $10-27^{\circ} \mathrm{C}$ and larvae are typically found in waters higher than $16^{\circ} \mathrm{C}$ (Moyse 1987).

Herein a clear SST gradient was found along Chilean coast and the encountered goose barnacles were differentially distributed within particular temperature ranges. Lepas anatifera declined in abundance between 21.2 and 18.2 ${ }^{\circ} \mathrm{C}$, while L. australis increased in abundance below $18.2{ }^{\circ} \mathrm{C}$. Lepas pectinata was not found at temperatures $<13.2{ }^{\circ} \mathrm{C}$, was most abundant at temperatures between 16.7 and $18.2{ }^{\circ} \mathrm{C}$, and declined at higher temperatures (Fig. 5, Table $1)$. The possible reason for the low abundances outside the temperature-specific range is probably due to these species being unable to settle, grow and/or reproduce successfully under sub-optimal conditions. As an alternative explanation, Moyse (1987) suggested that the spines of the larval states (nauplii) of Lepas spp. may be correlated with the different viscosity of water masses: the relatively shorter and vestigial spines of $L$. pectinata and $L$. australis respectively, may be correlated with the higher viscosity of the colder waters inhabited by these species, while the large spines of $L$. anatifera may be correlated with the lower viscosity of warm waters. Therefore, it can be expected that the larvae of these three barnacles show highest abundances in their respective species-specific SST range and are restricted to the water masses to which they are morphologically as well as physiologically adapted.

Contribution to the understanding of the biogeography of the south east Pacific

The present study only considers the distribution of three principal species of pelagic barnacles. Even though this is a very limited number of species for a biogeography study, the distribution of these three species revealed a clear separation of three zoogeographic zones, similar to those reported for littoral organisms. While the low number of species included in this study could be considered a drawback, it allows on the other hand to link knowledge of the biology of each species to the water masses in which it was found. The warmwater species, L. anatifera, was not found south of $33^{\circ} \mathrm{S}$ in the Peruvian-Chilean Province, and the West Wind Drift species, L. australis, was 
not detected north of $33^{\circ} \mathrm{S}$ in the Magellanic Province, whereas Lepas pectinata was most abundant in the Chilean Transition Zone where these two provinces overlap. A study by Foster (1978), including the lepadids from New Zealand, revealed a similar northern distribution for $L$. anatifera and L. pectinata, whereas L. australis was only encountered south of $39^{\circ} \mathrm{S}$. This author noted the overlap of these species in a central region and suggested that the surface currents and the prevailing SST were responsible for maintaining the distribution pattern observed, because the surface currents drive the distribution of floating substrata and SST directly affects the life cycle of individuals or restricts larval distribution. This together with the suggestion by Moyse (1987) on temperature-specific adaptations of larvae, indicates that indeed the larval states of these goose barnacles are restricted to certain water masses.

The distribution pattern reported herein for goose barnacles closely matches that of littoral benthic fauna. The species-specific SST association of goose barnacles suggests that a clear oceanographic influence exists along Chilean coast, and that SST itself and its influence on planktonic stages is the principal causal factor for the biogeographic patterns observed along the south east Pacific coast. For littoral mollusks, Rivadeneira \& Fernández (2005) found that $20 \%$ of the analyzed species changed their distributional range in accordance with changing gradients of SST. Astorga et al. (2003) also demonstrated that the pattern of SST is inversely proportional to the diversity of decapod crustaceans and argued that SST may affect the larval phases of these species. While these considerations provide support for the direct influence of SST (possibly via planktonic stages), we can not exclude the possibility that other factors modulate the observed distribution pattern (e.g., Knox 1960, Briggs 1995). Lancellotti \& Vásquez (1999) also revealed a link between SST and the distribution of benthic species, but they additionally mentioned that freshwater influx along the Chilean coast exhibits a clear latitudinal gradient, which may also influence the distribution of benthic species (highest amount of freshwater towards the south). Zvyagintsev \& Mikhajlov (1985) reported a massive death of $L$. anatifera at decreasing salinity, which could also contribute to the distributional patterns observed herein. Larvae of parasitic barnacles exhibit varying developmental times at different salinities (Kashenko \& Korn 2002), suggesting that salinity may also affect the distribution of goose barnacles.

While most authors agree on three geographical zones along the Chilean coast (e.g., Knox 1960, Lancellotti \& Vásquez 1999, 2000), the exact limits of these zones can vary substantially (see Camus 2001), possibly due to the effects of "El Niño-Southern Oscillation" ENSO (Thiel 2002, Escribano et al. 2003). In the present study, we found all four species of goose barnacles near San Antonio ( $\left.33^{\circ} \mathrm{S}\right)$ in the center of the transition zone, while at the other sampling areas only one or two of these species were observed. Thus, our results agree with previous biogeographic studies of benthic organisms, which report a peak of species richness in the transition zone (Lancellotti \& Vásquez 2000, Ojeda et al. 2000, Camus 2001, Rivadeneira et al. 2002, Thiel 2002, Hernández et al. 2005).

\section{CONCLUSIONS}

Along the south east Pacific coast there appears to exist a close match between the biogeography of planktonic and of littoral benthic organisms (Fagetti 1968, Antezana 1981, Ojeda et al. 2000, Camus 2001, Thiel 2002, Escribano et al. 2003, this study), just as there is in the north east Pacific (Newman 1979). Herein, we observed that the oceanographic conditions, mainly SST, are shaping the distribution of pelagic goose barnacles. This supports the hypothesis that the dispersal of organisms and their distribution along the Chilean Pacific coast is modulated by specific oceanographic conditions (SST, see Briggs 1995). Based on these considerations we suggest that the temporal distribution patterns of pelagic organisms and larvae may be highly variable in the central transition zone, in accordance with interannual variations in oceanographic conditions (e.g., ENSO). Studying interannual variability in the latitudinal distribution of the pelagic biota may contribute to a better understanding of the biogeographic limits along the Chilean coast. 


\section{ACKNOWLDEGEMENTS}

We sincerely acknowledge to all boat crews for their cheerful assistance during the surveys. We also acknowledge Juan José Garrido from Puerto Natales for logistic support. Eva Rothäusler helped with the initial translation of this manuscript. Two anonymous reviewers provided highly constructive comments that contributed significantly to the final manuscript. Funding provided by FONDECYT 1010356

\section{LITERATURE CITED}

ANTEZANA T (1981) Zoogeography of euphausiids in the south eastern Pacific Ocean. In: Vega M (ed) Memorias del Seminario sobre Indicadores Biológicos del Plancton: 5-23. UNESCO, Montevideo, Uruguay.

ARNAUD PM (1973) The genus Lepas Linné, 1758, from the French islands in the southern hemisphere and the Antarctic (Cirripedia). Crustaceana 24: 157-162.

ARNBOM T \& S LUNDBERG (1995) Notes on Lepas australis (Cirripedia, Lepadidae) recorded on the skin of southern elephant seal (Mirounga leonina). Crustaceana 68: 655-658.

ASTORGA A, M FERNÁNDEZ, E BOSCHI \& N LAGOS (2003) Two oceans, two taxa and one mode of development: latitudinal diversity patterns of South American crabs and test for possible causal processes. Ecology Letters 6: 420-427.

BARNES DKA \& P MILNER (2005) Drifting plastics and its consequences for sessile organism dispersal in the Atlantic Ocean. Marine Biology 146: 815-825.

BARNES DKA, LN WARREN, K WEBB, B PHALAN \& K REID (2004) Polar pedunculate barnacles piggy-back onpycnogona, penguins, pinniped seals and plastics. Marine Ecology Progress Series 284: 305-310.

BOETIUS J (1952-53) Some notes on the relation to the substratum of Lepas anatifera and Lepas fascicularis. Oikos 4: 112-117.

BRIGGS JC (1995) Global biogeography: developments in palaeontology and stratigraphy. Elsevier, Amsterdam, The Netherlands. 452 pp.

BRYAN SE, A COOK, JP EVANS, PW COLLS, MG WELLS, MG LAWRENCE, JS JELL, A GREIG \& R LESLIE (2004) Pumice rafting and faunal dispersion during 2001-2002 in the Southwest Pacific: record of a dacitic submarine explosive eruption from Tonga. Earth \& Planetary Science Letters 227: 135-154.

CAMUS PA (2001) Biogeografía marina de Chile continental. Revista Chilena de Historia Natural 74: 587-617.

CHENG L \& RA LEWIN (1976) Goose barnacles (Cirripedia: Thoracica) on flotsam beached at La Jolla, California. Fishery Bulletin 74: 212-217.

CLARKE KR (1993) Non-parametric multivariate analysis of changes in community structure. Australian Journal of Ecology 18: 117-143.

DANIEL A (1955) The Cirripedia of the Madras coast. Bulletin of the Madras Government Museum, New Series, Natural History Section (India) 6: 1-40.
DARWIN C (1852) A monograph of the Sub-class Cirripedia, with figures of all the species. The Lepadidae; or, Pedunculated Cirripedes. London, Ray Society (1851). 400 pp.

ESCRIBANO R, M FERNÁNDEZ \& A ARANÍS (2003) Physical-chemical processes and patterns of diversity of the Chilean east boundary pelagic and benthic marine ecosystems: An overview. Gayana Zoología (Chile) 67: 190-205.

EVANS F (1958) Growth and maturity of the barnacles Lepas hillii and Lepas anatifera. Nature 182: 12451246.

FAGETTI E (1968) Quetognatos de la expedición "Marchile I" con observaciones acerca del posible valor de algunas especies como indicadoras de las masas de agua frente a Chile. Revista de Biología Marina (Chile) 13: 85-171.

FIELD JG, CLARKE KR \& RM WARWICK (1982) A practical strategy for analysing multispecies distribution patterns. Marine Ecology Progress Series 8: 37-52.

FOSTER BA (1978) The marine fauna of New Zealand: barnacles (Cirripedia: Thoracica). New Zealand Oceanic Institute Memoirs 69, Wellington, New Zealand. $190 \mathrm{pp}$.

GOLLASCH S (2002) The importance of ship hull fouling as a vector of species introductions into the North Sea. Biofouling 18: 105-121.

GREEN A, PA TYLER, MV ANGEL \& JD GAGE (1994) Gametogenesis in deep- and surface-dwelling oceanic stalked barnacles from the NE Atlantic Ocean. Journal of Experimental Marine Biology and Ecology 184: 143-158.

GUDMUNDSSON F \& A INGÓLFSSON (1967) Goose barnacles (Lepas spp.) on surtsey pumice. Natturufraedingurinn (Icelana) 37: 222-235.

HELMUTH B, RR VEIT \& R HOLBERTON (1994) Longdistance dispersal of a subantarctic brooding bivalve (Gaimardia trapesina) by kelp-rafting. Marine Biology 120: 421-426.

HERNÁNDEZ CE, MORENO RA \& N ROZBACZYLO (2005) Biogeographical patterns and Rapoport's rule in southeastern Pacific benthic polychaetes of the Chilean coast. Ecography 28: 1-11.

HOBDAY AJ (2000a) Age of drifting Macrocystis pyrifera (L.) C. Agardh rafts in the southern California bight. Journal of Experimental Marine Biology and Ecology 253: 97-114.

HOBDAY AJ (2000b) Persistence and transport of fauna on drifting kelp (Macrocystis pyrifera (L.) C. Agardh) rafts in the southern California bight. Journal of Experimental Marine Biology and Ecology 253: 75-96.

IL'IN IN (1992) Pelagic epiboly in the tropical and subtropical waters of the ocean. In: Il'in IN (ed) Obrastaniye i biopovrezhdenya: 77-111. Nauka, Moscow, Russia.

KASHENKO SD \& OM KORN (2002) Adaptive responses of the larvae of cirripede barnacle Peltogasterella gracilis to changes in seawater temperature and salinity. Russian Journal of Marine Biology (Russia) 28: 317-323.

KITSOS MS, M CHRISTODOULOU, S KALPAKIS, M NOIDOU \& A KOUKOURAS (2003) Cirripedia thoracica associated with Caretta caretta (Linnaeus, 1758) in the northern Aegean Sea. Crustaceana 76: 403-409.

KNOX GA (1960) Littoral ecology and biogeography of the southern ocean. In: Pantin CFA (ed) A discussion of the biology of the southern cold 
temperate zone: 577-624. Proceedings of the Royal Society 152B, London, England.

LANCELLOTTI DA \& JA VÁSQUEZ (1999) Biogeographycal patterns of benthic macroinvertebrates in the southeastern Pacific littoral. Journal of Biogeography 26: 1001-1006.

LANCELLOTTI DA \& JA VÁSQUEZ (2000) Zoogeografía de macroinvertebrados bentónicos de la costa de Chile: Contribución para la conservación marina. Revista Chilena Historia Natural 73: 99-129.

MEMMI M (1980) A new subgenus and species of the genus Lepas (Crustacea, Cirripedia). Zoological Zhurnal (Russia) 59: 948-950.

MENZIES RJ (1962) The zoogeography, ecology and systematics of the Chilean marine isopods. Lunds Universitets Arsskrift N.F. Avdelningen 2 (Sweden) 57: 1-162.

MINCHIN D (1996) Tar pellets and plastics as attachment surfaces for Lepadid cirripedes in the North Atlantic Ocean. Marine Pollution Bulletin 32: 855859.

MOYSE J (1987) Larvae of lepadomorph barnacles. In: Southward AJ (ed) Barnacle biology: 329-362. Balkema, Rotterdam, The Netherlands.

NEWMAN WA (1972) Lepadids from the Caroline Islands (Cirripedia, Thoracica). Crustaceana 22: 31-38.

NEWMAN WA (1979) Californian transition zone: Significance of short-range endemics. In: Gray J \& AJ Boucot (eds) Historical biogeography, plate tectonics and the changing environments: 339-416. Oregon State University Press, Corvallis, Oregon, USA.

NEWMAN WA \& A ROSS (1971) Antarctic Cirripedia. American Geophysical Union, Antarctic Research Series 14: 1-257.

NILSSON-CANTELL CA (1929) Cirripeds from the Juan Fernandez Islands. In: Skottsberg C (ed) The natural history of Juan Fernandez and Easter Island 3: 483-492. Almquist \& Wiksels Boktryckeria B, Uppsala, Sweden.

NILSSON-CANTELL CA (1938) Cirripedes from the Indian Ocean in the collection of the Indian Museum, Calcutta. Memoirs of the Indian Museum (India) 13: 1-81.

NILSSON-CANTELL CA (1957) Thoracic cirripeds from Chile. Reports of The Lund University Chile expedition 1948-49. Lunds Universitets Arsskrift. N.F. Avdelningen 2. (Sweden) 53: 1-25.

OJEDA FP, F LABRA \& A MUÑOZ (2000) Patrones biogeográficos de los peces litorales de Chile. Revista Chilena de Historia Natural 73: 625-641.

PATEL B (1959) The influence of temperature on the reproduction and moulting of Lepas anatifera $\mathrm{L}$. under laboratory condition. Journal of the Marine Biological Association of the United Kingdom 38: 589-597.

RIVADENEIRA MM \& M FERNÁNDEZ (2005) Shifts in southern endpoints of distribution in rocky intertidal species along the south-eastern Pacific coast. Journal of Biogeography 32: 203-209.

RIVADENEIRA MM, M FERNÁNDEZ \& SA NAVARRETE (2002) Latitudinal trends of species diversity in rocky intertidal herbivore assemblages: spatial scale and the relationship between local and regional species richness. Marine Ecology Progress Series 245: 123-131.

SANO M, M OMORI \& K TANIGUCHI (2003) Predatorprey systems of drifting seaweed communities off the Tohoku coast, northern Japan, as determined by feeding habit analysis of phytal animals. Fisheries Science 69: 260-268.

SKERMAN TM (1958) Rates of growth in two species of Lepas (Cirripedia). New Zealand Journal of Science 1: 402-411.

SMITH JMB \& TP BAYLISS-SMITH (1998) Kelp plucking: coastal erosion facilitated by bull-kelp Durvillaea antarctica at subantarctic Macquarie Island. Antarctic Science 10: 431-438

THIEL M (2002) The biogeography of littoral algalassociated peracarids along the Pacific coast of Chile. Journal of Biogeography 29: 999-1008.

THIEL M \& L GUTOW (2005) The ecology of rafting in the marine environment. I. The floating substrata. Oceanography and Marine Biology: an Annual Review 42: 181-264.

THIEL M, I HINOJOSA, N VÁSQUEZ \& E MACAYA (2003) Floating marine debris in coastal waters of the SE-Pacific (Chile). Marine Pollution Bulletin 46: 224-231.

TSIKHON-LUKANINA EA, GG NIKOLAEVA \& OG REZNICHENKO (1986) Feeding spectra of oceanic epiboles. Okeanologiya (Russia) 26: 1006-1009.

YOUNG PS (1990) Lepadomorph cirripeds from brazilian coast. I - Families Lepadidae, Poecilasmatidae and Heteralepadidae. Bulletin of Marine Science 47: 641-655.

ZEVINA GB \& M MEMMI (1981) Distribution of the pelagic barnacle crustaceans in the Atlantic ocean with respect to anthropogenic factors. In: Rudyakova NA (ed) Epiboly and biological corrosion in aquatic medium: 99-109. Nauka, Moscow. Russia.

ZVYAGINTSEV AY \& SR MIKHAJLOV (1985) The formation of fouling communities on a longdistance ship in tropical waters. Biologiya Morya/ Marine Biology (Russia) 4: 16-20. 